\title{
Effects of reduced-impact logging on medium and large-bodied forest vertebrates in eastern Amazonia
}

\author{
Juliana Laufer ${ }^{1,4}$, Fernanda Michalski, ${ }^{1,2}$ \& Carlos A. Peres ${ }^{3}$ \\ ${ }^{1}$ Universidade Federal do Amapá, Programa de Pós-Graduação em Biodiversidade Tropical, Rod. Juscelino \\ Kubitschek, km 02, CEP 68902-280, Macapá, AP, \\ Brazil. \\ ${ }^{2}$ Instituto Pró-Carnívoros, C.P. 10, CEP: 12940-970, Atibaia, SP, \\ Brazil. \\ ${ }^{3}$ University of East Anglia, School of Environmental Sciences, Centre for Ecology, Evolution and \\ Conservation, Norwich, Norfolk, \\ United Kingdom. \\ ${ }^{4}$ Corresponding author: Juliana Laufer, e-mail: julianalaufer@yahoo.com.br
}

LAUFER, J., MICHALSKI, F., PERES, C.A. Effects of reduced-impact logging on medium and largebodied forest vertebrates in eastern Amazonia. Biota Neotropica. 15(2): e20140131. http://dx.doi.org/10. 1590/1676-06032015013114

\begin{abstract}
Standard line-transect census techniques were deployed to generate a checklist and quantify the abundance of medium and large-bodied vertebrate species in forest areas of eastern Amazonia with and without a history of reduced-impact logging (RIL). Three areas were allocated a total of 1,196.9 km of line-transect census effort. Sampling was conducted from April to June 2012 and from April to August 2013, and detected 29 forest vertebrate species considered in this study belonging to 15 orders, 20 families and 28 genera. Additionally, eight species were recorded outside census walks through direct and indirect observations. Of this total, six species are considered vulnerable according to IUCN (Ateles paniscus, Myrmecophaga tridactyla, Priodontes maximus, Tapirus terrestris, Tayassu peccary, Chelonoidis denticulata). Observed species richness ranged from 21 to 24 species in logged and unlogged areas, and encounter rates along transects were highly variable between treatments. However, the relative abundance of species per transect did not differ between transects in logged and unlogged forests. Of the species detected during censuses, only three showed different relative abundance between the two treatments (Saguinus midas, Tinamus spp. and Dasyprocta leporina). Our results show that the effect of RIL forest management was a relatively unimportant determinant of population abundance for most medium and large vertebrates over the time period of the survey.
\end{abstract}

Keywords: fauna, forest management, tropical rainforest, mammals, birds.

LAUFER, J., MICHALSKI, F., PERES, C.A. Efeitos da exploração de impacto reduzido em vertebrados de médio e grande porte na Amazônia oriental. Biota Neotropica. 15(2): e20140131. http://dx.doi.org/10. 1590/1676-06032015013114

Resumo: Técnicas padronizadas de censo por transecções lineares foram empregadas para gerar uma lista e quantificar a abundância de espécies de vertebrados de médio e grande porte em áreas de floresta na Amazônia oriental, com e sem uma história de exploração de impacto reduzido (EIR). Três áreas foram amostradas com um esforço total de $1.196,9 \mathrm{~km}$ de censo ao longo de transectos lineares. A amostragem foi realizada de abril-junho de 2012 e de abril-agosto de 2013, e detectou 29 espécies florestais de vertebrados consideradas neste estudo pertencentes a 15 ordens, 20 famílias e 28 gêneros. Adicionalmente, oito espécies foram registradas fora dos censos ao longo dos transectos por meio de observações diretas e indiretas. Desse total, seis espécies são consideradas vulneráveis de acordo com a IUCN (Ateles paniscus, Myrmecophaga tridactyla, Priodontes maximus, Tapirus terrestris, Tayassu pecari, Chelonoidis denticulata). A riqueza das espécies observada variou de 21 a 24 espécies em áreas com e sem corte seletivo, e as taxas de encontro ao longo dos transectos foram bastante variáveis entre os tratamentos. No entanto, a abundância relativa das espécies por transecto não diferiu entre florestas não exploradas e exploradas. Das espécies detectadas durante o censo, apenas três apresentaram diferentes abundâncias relativas entre os dois tratamentos (Saguinus midas, Tinamus spp. e Dasyprocta leporina). Nossos resultados mostram que o efeito do manejo florestal EIR não foi relativamente determinante para abundância populacional da maioria dos vertebrados de médio e grande porte.

Palavras-chave: Fauna, manejo florestal, floresta tropical, mamíferos, aves. 


\section{Introduction}

Maintaining viable populations of medium and largebodied vertebrates is essential if tropical forests are to maintain their current structure and composition (Wright et al. 2007, Terborgh et al. 2008, Gutierrez-Granados et al. 2010, Beck et al. 2013). For example, most Amazonian tree species are dispersed by forest vertebrates. In the Guiana Shield and Central Amazonia, frugivorous vertebrates disperse over 94\% of all woody plant species (Peres \& van Roosmalen 2002). Thus, surveys to assess the impact of any anthropogenic forest disturbance on faunal assemblages are essential to the understanding of biodiversity and ecological processes, as well as planning management and conservation strategies for forests and their constituent faunas (Willis et al. 2007).

However, despite the importance of medium and large vertebrates, extensive knowledge gaps still remain on these species (Paglia \& Fonseca 2009). In Amazonia, this lack of knowledge comes partly from the vast area and ensuing difficulties in accessing many areas, both of which hinder studies over much of the basin. Despite the physical remoteness of some areas, between 1988 and 2013 more than 9.5\% of primary forests across the Brazilian Amazon was either converted or severely degraded (INPE 2014) by various anthropogenic drivers including deforestation, forest fires, and fragmentation (Fearnside 2005, Michalski et al. 2008, Peres et al. 2010). To help minimize this impact, some 90 million hectares of Amazonian forests have been designated as Sustainable Use Protected Areas (SUPAs) (Peres 2011). Such areas are set aside for the sustainable use of natural resources, in addition to maintaining biodiversity and other ecological functions (Brazil 2000). Timber extraction is therefore a key economic activity in achieving the often intractable goal of reconciling financially viable land-use revenues and forest conservation within SUPAs.

Although controversial, selective logging has been widely promoted as one of the least harmful patterns of land use for tropical forest animal and plant communities (Johns 1991, Grove 2002, Meijaard \& Sheil 2008, Gibson et al. 2011, Kudavidanage et al. 2012). However, this activity can alter the composition and structure of the original forest (Peres et al. 2010). Observed changes include modifications in the amount of litter, leaves, flowers and the elimination of fruiting trees important to the trophic viability of frugivore populations (Johns 1988, Uhl \& Vieira 1989, Johns 1992, Chapman et al. 2000). In addition, a post-logging forest landscape may become more homogeneous (Kitching et al. 2013), potentially degrading habitats available for the vertebrate fauna. Studies across the humid tropics on the impacts of logging on forest biodiversity are plagued by a myriad of methodological problems (Laufer et al. 2013). Ideally, effectively assessing the impacts of selective logging requires a proper understanding of the structure and composition of forests and their wildlife both before and after logging (Johns 1986, Kohler et al. 2002, Potts 2011, Samejima et al. 2012). This prevents spatially biased, pseudo-replicated, or intrinsically flawed assessments of the effects of selective logging on wildlife, because it retains the original distribution and composition of resident species across treatments (Peres et al. 2010).

The potentially detrimental effects of logging on wildlife can be reduced with the use of management techniques that minimize the effects of disturbances, such as different forms of reduced-impact logging (Putz et al. 2008). This technique consists of planning management actions to minimize the direct and indirect impacts of logging, and to maintain both ecosystem processes and the economic and environmental viability of the activity (Barreto et al. 1998, Putz et al. 2008). RIL typically has a lower cutting intensity than other forms of timber extraction and studies typically report lower levels of collateral damage than those induced by more traditional techniques. RIL is reported to induce lower rates of species loss (Whitman et al. 1998, Azevedo-Ramos et al. 2006, Samejima et al. 2012), minimize the amount of canopy openings, reduce collateral damage (Uhl \& Vieira 1989, Bicknell \& Peres 2010) and thereby reduce the probability of post-cutting forest fires (Nepstad et al. 1999).

However, our understanding of the effects of forest perturbation associated with RIL on forest fauna, particularly on medium and large-bodied vertebrates, remains very poor. The aim of this study, therefore, was to use standardized wildlife census techniques to inventory the medium and large vertebrate fauna in order to provide both a species checklist and estimate the richness and relative abundance of vertebrate populations at an eastern Amazonian forest landscape providing a RIL-disturbed and undisturbed forest mosaic. For this we collected data within three different areas: one that had never been exposed to selective logging, another 2-3 years after RIL disturbance, and the third including both pre- and postdisturbance one year after a selective cutting operation had occurred. We predict that patterns of species abundance, if not species composition, would remain unchanged. This prediction can be expected due the well conserved landscape, proximity to unlogged forest, and the management forest applied on the forests (RIL). However, we expect to detect the influence of RIL on the abundance of at least some species, particularly on the abundance of those strict forest specialist species, due to their undisturbed old growth ecological requirements.

\section{Methods}

\section{Study Area}

The study was conducted in the Rio Jari basin of northeastern Pará, eastern Brazilian Amazonia, within a vast private landholding controlled by Jari Florestal (hereafter, Jari landscape) $\left(00^{\circ} 27^{\prime} 00^{\prime \prime}-01^{\circ} 30^{\prime} 00^{\prime \prime} \mathrm{S} ; 51^{\circ} 40^{\prime} 00^{\prime \prime}-53^{\circ} 20^{\prime} 00^{\prime \prime} \mathrm{W}\right.$; Figure 1). This company manages an area of approximately $1,260,000$ ha in the transition region between the lowland Amazon and the Guianan Highlands (Souza 2009). Between the 1960s and 1990s, approximately $10 \%$ of the landholding area consisting of primary forest was converted to plantations of fast-growing exotic trees (Barlow et al. 2010). The site is currently characterized by a large-scale mosaic of Eucalyptus plantations ( 45,000 ha), secondary forest abandoned for some 20-25 years ( $>50,000 \mathrm{ha})$, and a vast area of primary forest $(\sim 1$ million ha) subjected to extremely low levels of human disturbance (Barlow et al. 2007, Gardner et al. 2007, Parry et al. 2007). The predominant vegetation within the Jari study landscape is dense lowland, submontane and montane rain forest, seasonallyflooded forest (igapó), open evergreen lowland forest, submontane forest with lianas and submontane forest with palms (Souza 2009). The canopy cover (25-50 m tall) is continuous (Souza 2009), and the dominant emergent tree species is the commercially valuable Angelim Vermelho (Dinizia excelsa Ducke). 
The average annual rainfall is $2,115 \mathrm{~mm}$, with an average annual temperature of $26^{\circ} \mathrm{C}\left(22^{\circ}-34^{\circ} \mathrm{C}\right)$ (Ribeiro et al. 2008, Souza 2009). The three driest months of the year experience $60 \mathrm{~mm}$ lower precipitation (RADAM 1974). Soils consist mostly of yellow oxisols, inceptisols and podzolics. Other soil types, such as the ultisol and plinthosols, occur in smaller patches. The soils of upland forests vary in their proportions of sand, clay and silt, and include gravel to a greater or lesser extent (Souza 2009).

\section{Survey Areas}

Our field sampling took place in three Annual Operating Plots (POAs - from the Portuguese acronym, Planos Operacionais Anuais) (Figure 1). These contiguous areas span over $450 \mathrm{~km}^{2}$. We sampled two areas before the intervention of selective logging: control area (POA-08) and POA-0 $7_{\text {PRE. These }}$ areas had been exposed to low levels of human impact (e.g.: subsistence hunting and a low density of narrow unpaved roads). In POA-07, two long-established roads ( $>20$ years) were supplemented by $8 \mathrm{~km}$ of recent logging roads ( $>2$ years) to support forest management activities. The control area had some $20 \mathrm{~km}$ of much older roads ( $>25$ years) built by the company for forest inventories of the area. Two other areas were sampled after they had been exposed to RIL, POA-07 (logged in 2012) and POA-06 (logged in 2010-2011). POAs-07 and 08 were surrounded to the north by $>20$ year-old secondary forests and tree plantations (Eucalyptus plantations). To the south of POA-06 $(>2 \mathrm{~km})$ lay a region where RIL disturbance had taken place between 2006 and 2008. The other sampling areas were embedded within a vast matrix of undisturbed primary forest. All areas had been exposed to little or no hunting pressure. Throughout the entire time period of eight months of fieldwork, we detected fewer than ten signs of any present or past hunting activity (including vehicle tracks, hunting traps, direct encounters with hunters, spent shells, and gunfire shots).

POA-07 and POA-06 were cut according to reduced-impact logging techniques. These aim to minimize logging impacts through careful planning of access roads and transportation, a $100 \%$ forest inventory of the area to be managed, selection of individual trees for cutting ( $\mathrm{DBH}>50 \mathrm{~cm}$ ), and control of tree felling direction, among other mitigating measures to minimize collateral damage. The maximum cutting intensity allowed for these areas was 3-4 individual trees $\cdot \mathrm{ha}^{-1}$ (or $30 \mathrm{~m}^{3}$ of sawable timber per ha), which is similar to other Amazonian sites (Uhl \& Vieira 1989). The minimum cut-off of logging intensity applied to the surveyed areas varied according to the spatial distribution of species of high commercial value and abiotic characteristics of the region (e.g. topography and drainages). The logged areas (POA-07 $7_{\text {POST }}$ and POA-06) were harvested at low intensity $\left(22.8 \mathrm{~m}^{3} \cdot \mathrm{ha}^{-1}\right)$. This logging intensity and the resulting collateral damage amounted to a $16.9 \%$ reduction in

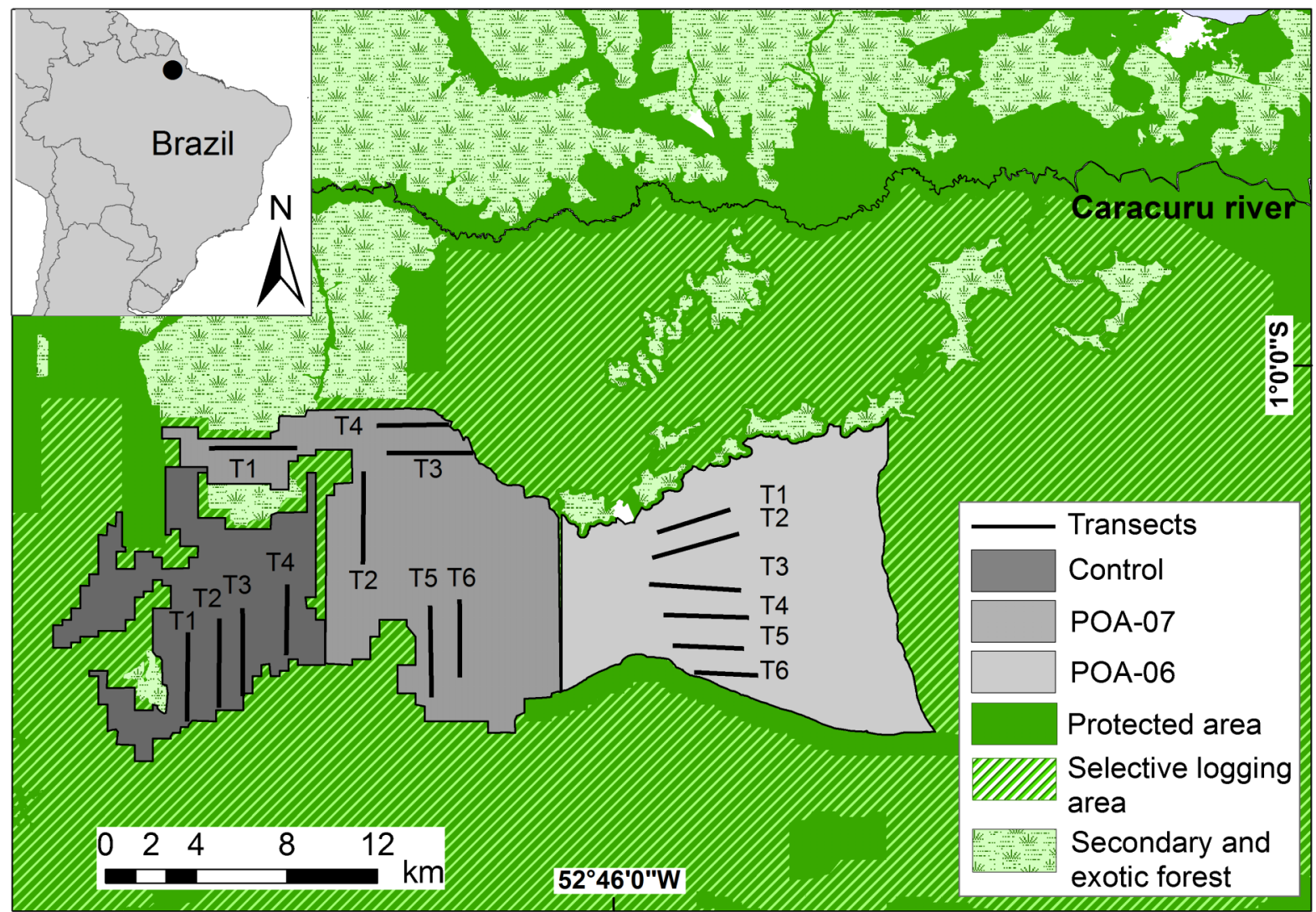

Figure 1. Location of the three study sites where medium and large-bodied vertebrates where surveyed in the municipal county of Almeirim, Pará, Brazil. Gray areas indicate those selected for the study, control, POA-07 (pre- and post-logging) and POA-06 areas. The green area indicates a legal forest reserve (LR) within the Jari study landscape and the hatched area, superimposed onto the LR, is the total area allocated to low-impact selective logging. Therefore, only the area south of POA-06 had been previously logged prior to this study ( $<6$ years). 
forest basal area, compared to the basal area of the unlogged forest used as a control (J. Laufer, unpublished data).

\section{Vertebrate censuses}

We conducted two sessions of line-transect censuses of vertebrates over a 2-year period. The first sampling session occurred between April and June 2012, when we sampled POA07 before selective logging intervention (POA-07 $7_{\mathrm{PRE}}$ ). The second, between April and August 2013, sampled an area without intervention of selective logging, and another two with one and 2-3 years post-harvesting, respectively $\left(\mathrm{POA}_{\mathrm{Control}}\right.$, POA-0 $7_{\text {POST }}$ and POA-06). We avoided sampling any site during the months of July-December, when selective cutting normally takes place. To sample medium and large $(>250 \mathrm{~g})$ vertebrates, we used a standardized line-transects census technique adjusted to local conditions (Peres \& Cunha 2011). The census was conducted by observers with at least three years of experience of monitoring neotropical forest fauna. In total, a census effort of $1,196.9 \mathrm{~km}$ of line transect walks was accumulated in both unlogged treatments, POA-0 $7_{\text {PRE }}$ and POA $_{\text {Control }}$ (henceforth, UL), and logged forest (LF) treatments, POA-07 $7_{\text {POST }}$ and POA-06. In each area between four and six linear transects of 3.2 to $4.5 \mathrm{~km}$ in length were cut, marked every $50 \mathrm{~m}$, and mapped using a handheld GPS (Table 1). To maintain spatial independence, we spaced all transects by a minimum distance of $1 \mathrm{~km}(1-1.9 \mathrm{~km}$, mean $=1.2 \mathrm{~km}, \mathrm{SD}=$ \pm 0.2 ). Each transect was walked at least 7 times in the morning and 3 to 7 times in the afternoon. To minimize possible sampling bias and randomly reshuffle observer effects, observers in each treatment were systematically rotated.

We followed the sampling protocol proposed by Peres \& Cunha (2011) to census all diurnal forest vertebrate species larger than $250 \mathrm{~g}$. Transects were walked at an average velocity of $1.25 \mathrm{~km} \cdot \mathrm{h}^{-1}$ (Buckland et al. 2010a, b), which allows the use of both auditory and visual detections across all strata of the forest (Peres \& Cunha 2011). We systematically stopped for up to $1 \mathrm{~min}$ approximately every $100 \mathrm{~m}$ along transects to increase the likelihood of acoustic detections. Census work took place in the morning between 06:00 $\mathrm{h}$ and 11:00 $\mathrm{h}$ and in the afternoon from 13:30 h to $16: 30 \mathrm{~h}$. The sampling period varied with the logistics of each area and the vagaries of weather conditions. Censuses were discontinued during periods of mild to heavy rainfall, because under such conditions auditory detection is impaired and animals become less active (Peres 1999).

For each detection we recorded time, species and distance along the transect. For all small and large tinamous species (Crypturellus spp. and Tinamus spp., respectively), we grouped detection data by genus, due to inherent difficulties in identifying these birds to species during censuses (Bicknell \& Peres 2010). To boost the detection power of vertebrate species occupancy (presence/absence) data we used both direct and indirect observations (presence of tracks, feces, hair and burrows) obtained along transects, as well as along the survey areas. Those ancillary data were also obtained when survey transects were being initially opened and during movements on foot between transects.

\section{Data Analysis}

To analyse whether the cumulative sampling effort in different areas was representative of the medium and large vertebrate assemblage we constructed per-transect species richness rarefaction curves, in which all visual and acoustic observations were combined. We analyzed data using the vegan (Oksanen et al. 2013) and indicspecies packages (De Cáceres \& Jansen, 2014) with the $\mathrm{R}$ program function specaccum and multipatt, respectively ( $\mathrm{R}$ Development Core Team 2013). ANOVAs were applied to perpendicular detection distances from transects (for both visual and acoustic records) to examine the variation in lateral detectability between the two treatments

Table 1. Sampling effort along different line transects in both logged and unlogged forest, length of transects ( $\mathrm{km})$, total distance censused $(\mathrm{km})$, and encounter rates for all vertebrate species (visual and acoustic detections per $10 \mathrm{~km}$ walked) for each transect/treatment.

Unlogged Forest

\begin{tabular}{|c|c|c|c|c|c|c|c|}
\hline \multicolumn{4}{|c|}{ POA-07 (PRE) } & \multicolumn{4}{|c|}{ Control } \\
\hline Transect & Length (km) & Total (km) & Encounter rate & Transect & Length (km) & Total (km) & Encounter rate \\
\hline $\mathrm{T} 1$ & 4.1 & 51.4 & 11.7 & $\mathrm{~T} 1$ & 3.9 & 75.0 & 14.1 \\
\hline $\mathrm{T} 2$ & 4.2 & 49.8 & 13.1 & $\mathrm{~T} 2$ & 3.9 & 65.9 & 13.5 \\
\hline $\mathrm{T} 3$ & 4.0 & 40.0 & 14.3 & $\mathrm{~T} 3$ & 4.0 & 69.1 & 23.7 \\
\hline $\mathrm{T} 4$ & 3.2 & 37.8 & 15.1 & $\mathrm{~T} 4$ & 3.2 & 66.6 & 15.9 \\
\hline T5 & 4.1 & 53.0 & 11.9 & & & & \\
\hline T6 & 3.4 & 44.2 & 9.5 & & & & \\
\hline TOTAL & 22.9 & 276.2 & 12.4 & TOTAL & 15.0 & 276.5 & 16.8 \\
\hline \multicolumn{8}{|c|}{ Logged Forest } \\
\hline \multicolumn{4}{|c|}{ POA-07 (POST) } & \multicolumn{4}{|c|}{ POA-06 (POST) } \\
\hline Transect & Length (km) & Total (km) & Encounter rate & Transect & Length (km) & Total (km) & Encounter rate \\
\hline $\mathrm{T} 1$ & 4.1 & 55.9 & 13.8 & $\mathrm{~T} 1$ & 3.8 & 52.5 & 10.5 \\
\hline $\mathrm{T} 2$ & 4.2 & 58.1 & 7.7 & $\mathrm{~T} 2$ & 4.5 & 63.0 & 11.0 \\
\hline T3 & 4.0 & 54.5 & 9.9 & T3 & 3.8 & 62.3 & 9.5 \\
\hline $\mathrm{T} 4$ & 3.2 & 43.6 & 15.3 & $\mathrm{~T} 4$ & 4.5 & 57.4 & 8.9 \\
\hline $\mathrm{T} 5$ & 4.1 & 57.1 & 12.1 & $\mathrm{~T} 5$ & 3.8 & 49.0 & 11.4 \\
\hline T6 & 3.4 & 47.6 & 13.9 & T6 & 4.5 & 43.4 & 14.1 \\
\hline TOTAL & 22.9 & 316.6 & 11.9 & TOTAL & 24.8 & 327.6 & 10.7 \\
\hline
\end{tabular}


Vertebrates in selectively logged forests

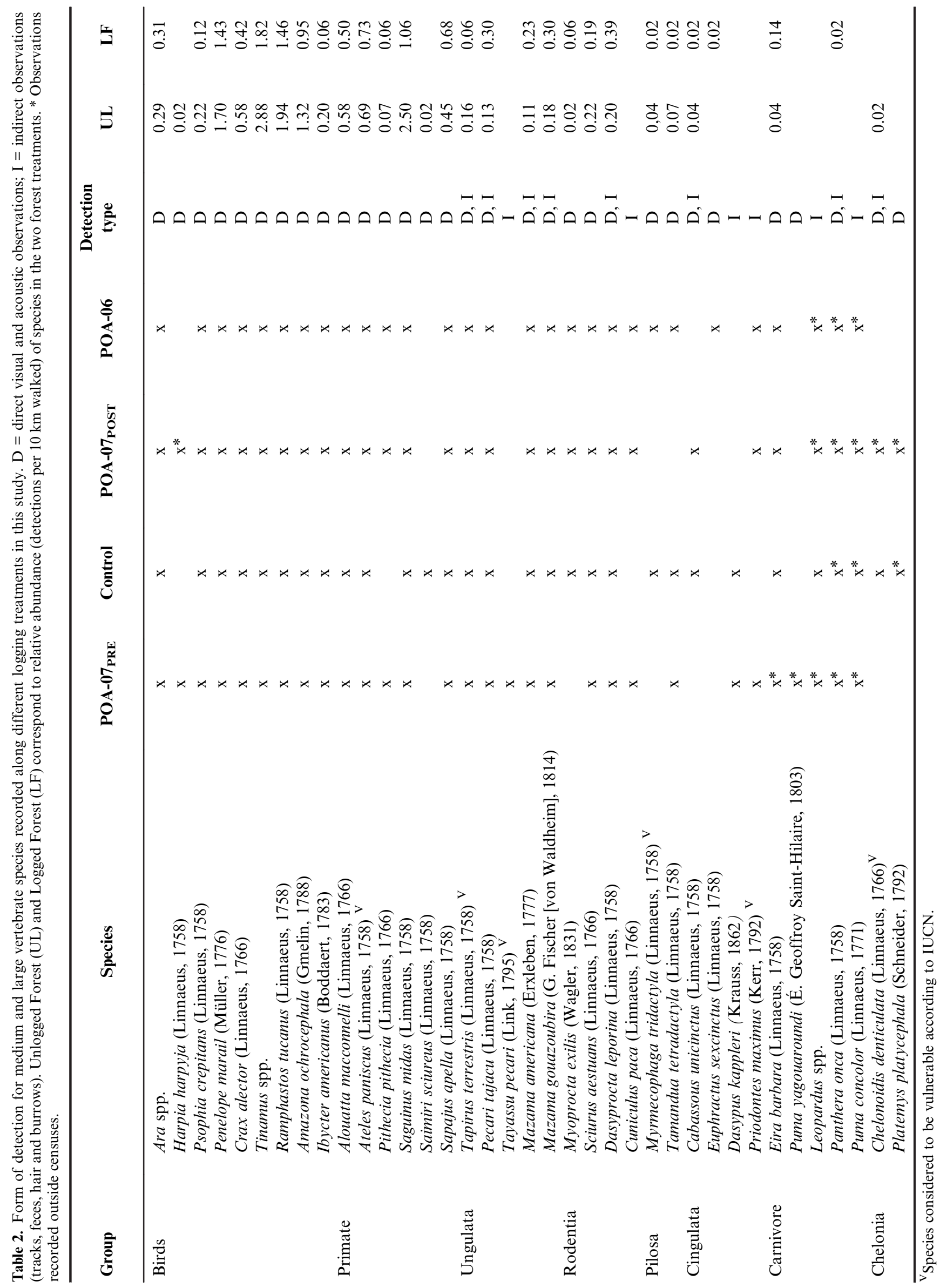



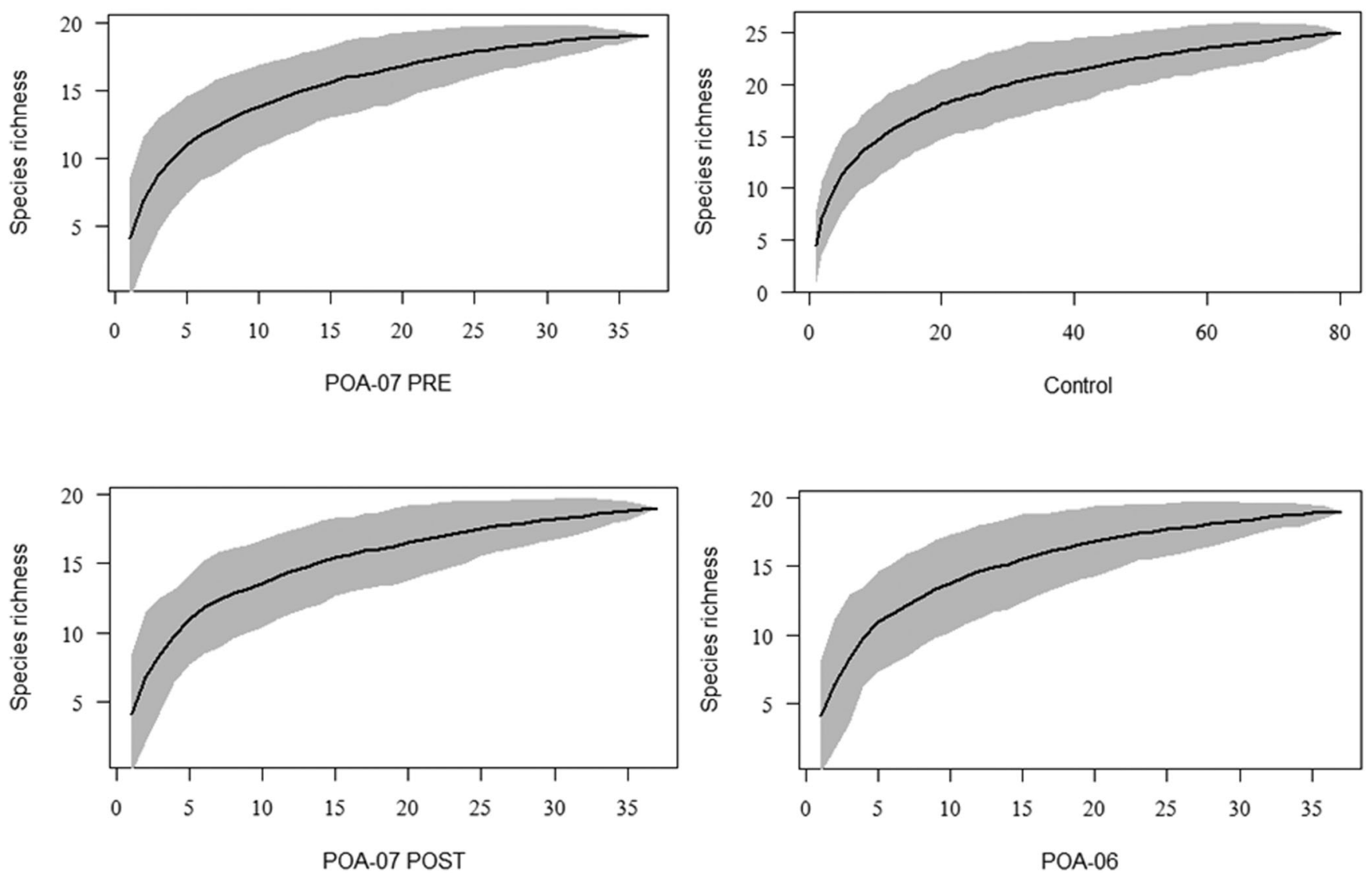

Figure 2. Cumulative species richness curve for medium and large vertebrates across the four study sites showing the $95 \%$ confidence intervals (gray areas). All four sampling areas reached asymptotes.

(Endo et al. 2010). We use the canonical significance threshold of $\mathrm{P}>0.05$ to accept the null hypothesis that there were no significant differences between treatments.

We combined data from visual and acoustic records to calculate the relative abundance of different species (detections every $10 \mathrm{~km}$ traveled on linear transects). We excluded from estimates of relative abundance all perpendicular distances farther than $50 \mathrm{~m}$ from transects to minimize the influence of detectability bias (Michalski \& Peres 2007). Due to the low number of detections $(\mathrm{N}<30)$ for most species, we did not attempt to derive a population density index (Buckland et al. 2010b). We used a non-parametric, Mann-Whitney test to examine differences between treatments (logged and unlogged areas). We considered transects in each POA as independent samples due to the minimum distance of $1.0 \mathrm{~km}$ between them. We also used an indicator analysis to understand which species differ in abundance between logged and unlogged areas (De Cáceres \& Legendre 2009). For this analysis we used the relative frequency of each species in the indicator value index between unlogged and logged forests.

\section{Results}

Considering all line-transect censuses, we recorded a total of 29 species of medium and large vertebrates from 20 families, 15 orders and 28 genera. We also recorded eight additional species through direct and indirect observations outside systematic census routines (Table 2). Of the species total, six are considered Vulnerable by the International Union for Conservation of
Nature (IUCN) (Table 2). Of all 1,537 detection events (visual and acoustic) obtained in 2012 (POA-07 PRE) and 2013 (other POAs), 809 took place in unlogged areas and 728 in logged areas. Overall encounter rates along transects in unlogged areas was significantly higher than in logged areas $\left(\mathrm{U}_{10,12}=90, \mathrm{P}=0.05\right)$. The average encounter rate per $10 \mathrm{~km}$ walked in unlogged and logged areas was $14.27(\mathrm{SD}= \pm 3.80)$ and $11.48(\mathrm{SD}= \pm 2.33)$, respectively (Table 1). The ANOVAs of overall lateral detectability of all species detected among the four sampling areas was not significantly different $(\mathrm{P}=0.056-0.881$, mean $\pm \mathrm{SD}=0.499 \pm$ $0.270)$. Species accumulation curves for the four areas suggest that the overall sampling effort deployed adequately sampled the medium and large vertebrate fauna of the Jari landscape (Figure 2).

The overall species richness detected in UL and LF areas was similar, ranging from 21 to 24 species. This variation was greater (10 - 19 species) if we consider individual transects within unlogged and logged forest treatments. Species richness was lower in transects at unlogged areas than in transects at logged areas, although the difference was not significant $\left(\mathrm{U}_{10,12}=40.5, \mathrm{P}=0.20\right)$. The unlogged area had an average of 14.4 species $(\mathrm{SD}= \pm 2.6)$ detected every $10 \mathrm{~km}$ walked, while logged areas had an average of 15.8 species ( $\mathrm{SD}= \pm 1.48)$. Only one species occurred exclusively in $\mathrm{UL}$ areas, the squirrel monkey (Saimiri sciureus), while the sixbanded armadillo (Euphractus sexcinctus) was only detected in LF areas, but none of these species can be considered specialists of either logged or unlogged forests. The indicator analysis revealed the association of distribution pattern of four species (Ara spp. ( $\mathrm{P}=0.001)$, Dasyprocta leporina $(\mathrm{P}=0.006)$, Pecari tajacu $(\mathrm{P}=0.022)$ and Eira barbara $(\mathrm{P}=0.028))$ with 


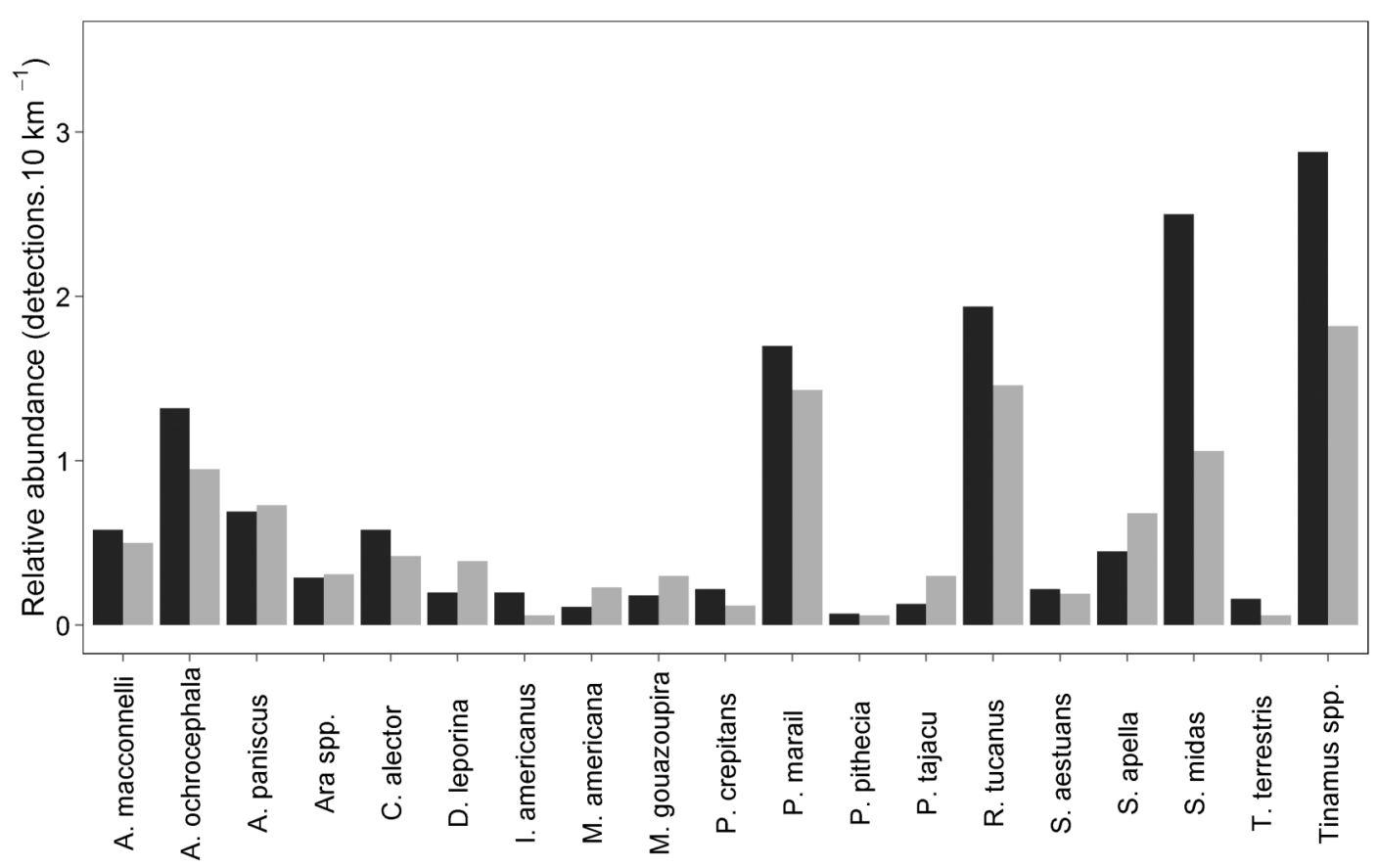

Figure 3. Change in relative abundance (detections $10 \mathrm{~km}^{-1}$ walked) of the main species detected in the two forest treatments (black: Unlogged Forest; gray: Logged Forest).

LF areas. On the other hand, we did not find any species that were significantly associated with UL areas.

Relative species abundance per transect did not differ between UL and LF areas $\left(\mathrm{U}_{144,190}=14744.5, \mathrm{P}=0.19\right)$ (Figure 3). The mean abundance was $0.99( \pm 1.02)$ and 0.73 $( \pm 0.65)$ detections $\cdot 10 \mathrm{~km}^{-1}$, respectively. The five most abundant species in UL and LF areas were the same (except for POA-06). These included a small-bodied callitrichid primate, the golden-handed tamarin (Saguinus midas) and four birds: white-throated toucan (Ramphastos tucanus), large tinamous (Tinamus spp.), yellow-crowned amazon (Amazona ochrocephala) and marail guan (Penelope marail). The difference in POA-06 is attributed to the presence of spider monkey (Ateles paniscus), the fourth most abundant species (1.0 detection $\bullet 10$ $\mathrm{km}^{-1}$ ) at this site.

Three species showed significantly different relative abundances between the two treatments. $S$. midas showed increased abundance in unlogged forest compared to logged forest $\left(\mathrm{U}_{10,12}\right.$ $=100, \mathrm{P}<0.001)$, with means of $2.3( \pm 1.1)$ and $1.0( \pm 0.7)$ detections $\cdot 10 \mathrm{~km}^{-1}$, respectively. The same pattern was observed for large tinamous, in that their relative abundance was $62 \%$ lower in logged compared to unlogged areas $\left(\mathrm{U}_{10,12}=\right.$ $108, \mathrm{P}<0.001)$. Agouti (D. leporina) was the only species with the highest relative abundance in logged areas $\left(\mathrm{U}_{10,12}=26.5\right.$, $P=0.03)$, with mean encounter rates of $0.14( \pm 0.25)$ and 0.41 $( \pm 0.31)$ for unlogged and logged forest areas, respectively. Moreover, this species was detected in 11 of 12 transects censused in logged areas, but in only three of the 10 transects censused in unlogged areas.

\section{Discussion}

Timber extraction in Amazonian forests holds a huge potential for growth in terms of both spatial extent and revenue (FAO 2010, Shearman et al. 2012), and this is often considered a relatively benign land-use in terms of biodiversity responses to selective logging (Gibson et al. 2011). Despite its importance in the neotropics, there are still insufficient studies attempting to understand the effects of tropical forest timber extraction on medium and large vertebrates (Laufer et al. 2013). In addition, whether logging induces either positive or negative impacts on forest fauna remains unclear, as studies have found different results. For example, studies conducted in similar forests on the French Guiana showed opposite results for the trends on abundance of two species groups (Psophia crepitans and Tinamous) (Thiollay 1997, Bicknell \& Peres, 2010). As we predicted, this study suggests that reduced-impact selective logging in itself did not strongly affect the species composition and relative abundance of the medium and large vertebrate populations, except for a few species. These results are consistent with other assessments of the degree to which RIL disturbance in tropical forests affects forest biotas (AzevedoRamos et al. 2006, Bicknell et al. 2014). The largely unaltered population abundances may result from the interaction of several factors, such as low levels of basal area removal and collateral damage, conserved landscape context and proximity to unlogged forest, and resilient life histories of several species.

A total of 28 of the 37 medium and large-bodied vertebrate species recorded had already been detected in other studies conducted in the Jari study landscape (e.g. Parry et al. 2007, 2009). However, our study detected nine additional taxa, including harpy eagle (Harpia harpyja), jaguarundi (Puma yagouaroundi), Brazilian squirrel (Sciurus aestuans), southern anteater (Tamandua tretradactyla), greater long-nosed armadillo (Dasypus kappleri), six-banded armadillo (E. sexcinctus), southern naked-tailed armadillo (Cabassous unicinctus), yellowfooted tortoise (Chelonoidis denticulata) and twist-neck turtle (Platemys platycephala) (Table 2). This is largely a function of our greater sampling effort compared to previous studies in the area, which increased the detection probability of these species. 
In addition, earlier studies in the region partly focused on secondary forests after 18-23 years of regeneration. In these species, E. sexcinctus and D. kapleri were exclusively observed in logged and unlogged forests, respectively (Table 2). E. sexcinctus is known to use dry areas of wooded scrub (cerrados) and the boundaries between secondary and primary forest (Sousa e Silva Junior \& Nunes 2001). The fact that this species was restricted to logged forests therefore supports the disturbance effect induced by RIL. On the other hand, $D$. kappleri is a well known primary forest species (Eisenberg 1989), but is often missing from hunted disturbed forests (e.g. Stone et al. 2009, Sampaio et al. 2010). P. yagouaroundi was recorded while moving between different sites within unlogged forest, but this species occurs in a broad range of both open and closed habitats, as well as fragmented and disturbed areas with exotic tree plantations (Michalski et al. 2006). The other six species did not show any clear pattern, being recorded in both unlogged and logged forests.

We uncovered widely variable encounter rates on transects within different forest treatments. This variation was largely due to the higher encounter rates in the control area (Table 1). However, the overall relative abundance did not differ across the two treatments. This indicates that RIL did not induce detectable changes in the relative abundance of medium and large vertebrates between UL and LF areas, at least within 6-18 month recovery time frame documented here. Only three taxa (S. midas, Tinamus spp. and D. leporina) showed significant differences in their relative abundances between treatments. This likely reflects the different ecological requirements of individual species (Bicknell \& Peres 2010), variation in their resilience to different disturbance levels, and time required to recovery from RIL disturbance.

Two species that were more significantly abundant in UL areas - golden-handed tamarin and large tinamous — which Tinamus spp. is relatively intolerant to selective logging (Thiollay 1992, 1997, Mason 1996). However, the response of golden-handed tamarin was unexpected, given that this specie is a generalist insectivore-frugivore (Pack et al. 1999), and are widely found in secondary forest (Rylands \& Keuroghlian 1988). As such, we would expect this species to increase in relative abundance in logged areas. Lower food resource availability in logged areas is a possible explanation, as some key food trees for this species, such as Manilkara bidentata (Oliveira \& Ferrari 2000), were exploited in the study area. Moreover, other food trees could have been affected by collateral damage from RIL. During the planning and execution phases of RIL cutting activities, several commercially valuable tree species bearing large fruits and seeds may be safeguarded (Putz et al. 2008), whereas forest species with minor or no commercial value are more often damaged during the implementation of roads, skid trails and roundlog storage areas. However, trees earmarked to be logged may have their felling planned so as to not damage seedlings and saplings for a second cutting cycle (Putz et al. 2008, Macpherson et al. 2012). So, until sufficient regeneration occurs in areas exposed to collateral damage, the abundance of golden-handed tamarin in recently-logged areas may decline because they prefer fruits with medium and small seeds (Oliveira \& Ferrari 2000), and preferentially inhabit low-and middle strata vegetation (Randarshan et al. 2011).

The only species that apparently benefited from the structural disturbance accompanying RIL was D. leporina.
This is consistent with studies evaluating this species in other selective logged neotropical forests (Bicknell \& Peres 2010). The increase in relative abundance in the area logged is possibly due to behavioral plasticity of this species, which can subsist in even small forest fragments (Jorge 2008, Norris et al. 2010). Moreover, our indicator analysis suggests that $D$. leporina could be defined as an indicator species of logged forests. The same applies to E. barbara that was more often recorded in logged forests. Both of these two species are known to prefer or tolerate disturbed forest habitats (Presley 2000, Jorge 2008), so their grouping with logging indicator taxa supports the notion that these species can subsist in large areas of RIL-disturbed forests.

In general, we found that reduced-impact logging did not affect the species composition and relative abundance of most medium and large-bodied vertebrates. The apparent lack of change in species composition and abundance can be explained by the life-history characteristics of the species in this study. Medium and large vertebrates are generally highly mobile, ensuring that they can move around the landscape, migrating to more suitable areas compared to areas affected by RIL (Azevedo-Ramos et al. 2006, Schleuning et al. 2011). In addition to species mobility, two important features of the landscape in the study area must be considered. The first feature is the presence of relatively large areas without any history of RIL disturbance immediately adjacent to areas with RIL activities. One of the guidelines of RIL planning is the choice of areas with gentle topography and high concentrations of tree species with high commercial value (Thiollay 1992, Putz et al. 2001). This fact allows for the persistence of "islands" of unlogged areas surrounded by logged ones. The second is the relatively well preserved matrix of the survey areas. Areas without any RIL disturbance can become a refuge for vertebrate species during reduced-impact logging operations, later acting as a recolonization source for the harvested areas (Johns 1996, Willot et al. 2000). Thus, interstitial areas of unlogged forests in our study landscape are likely to play a critical role in maintaining medium and large vertebrate populations throughout the RIL long-term cutting cycles of the overall forest mosaic.

However, there are other factors that can influence species responses to selective timber extraction. Recovery time, for example, can strongly influence assessments of the effects of selective logging (Putz et al. 2001, Jones et al. 2003, Clark et al. 2009). The response of organisms may have a time lag due to species-specific ecological factors, such as low reproductive rates and high longevity (Chapman et al. 2000, Owiunji 2000). As the recovery time between the end of RIL disturbance associated and field sampling was relatively short in this study (6-18 months), our conclusions should be interpreted with caution. Indeed, longer-term studies should be carried out in selectively logged areas to track how resident populations respond over time (Michalski \& Peres 2013). Ecological monitoring in such areas would also help researchers understand the synergistic interactions between RIL and conventional selective logging and other structural or non-structural human-induced forest disturbances (Peres et al 2010). These may occur before or after selective cutting, and may include natural succession following droughts and hurricanes (Whitman et al. 1998, Chapman et al. 2000), overhunting of large-bodied vertebrates (De Thoisy et al. 2005, Poulsen et al. 2009) and forest wildfires (Uhl \& Vieira 1989, Cochrane \& Laurance 2002, Barlow \& Peres 2008, FAO 2010). 
This study has helped to understand the short-term responses of medium and large vertebrate populations to large-scale RIL operations in lowland tropical forests. However, there is still a long way to go to fully understand the effects of such RIL impacts in different areas, floristic contexts, landscapes and species assemblages, both within and outside Amazonia. This may yield data to improve our understanding of how to manage the $>45$ million hectares of forest available for multiple natural resource use across the Brazilian Amazon alone (Bandeira et al. 2010). Monitoring of species contributing to forest regeneration (Wright et al. 2007, Terborgh et al. 2008) during the recovery process of selectively exploited forests should be undertaken by private companies, government agencies and local communities. With proper management, areas under low-impact selective logging can greatly contribute to the persistence of viable populations of most forest vertebrate species.

\section{Acknowledgements}

This study was funded by the Department of Science and Technology of Amapá (SETEC) / Foundation of Research of Amapá (FAPEAP) (Thesis grant No. 35.000.058/2012-SETEC). We would like to thank Jari Florestal for logistical and technical support during field activities. We also thank the Long-term Monitoring Program (LTER), the Federal University of Amapá and field assistants who helped in the data sampling. We thank two anonymous referees for constructive comments on the manuscript. JL was funded by a doctoral scholarship from the Coordination of Improvement of Higher Education Personnel (CAPES).

\section{References}

AZEVEDO-RAMOS, C., DE CARVALHO O. \& DO AMARAL, B.D. 2006. Short-term effects of reduced-impact logging on eastern Amazon fauna. Forest Ecol. Manag. 232(1-3):26-35.

BANDEIRA, R., VERÍSSIMO, A., COSLOVSKY, S., PEREIRA, J. \& QUINTELLA, R. 2010. Potencial Econômico nas Florestas Estaduais da Calha Norte: madeira e castanha-do-Brasil. Instituto do Homem e Meio Ambiente da Amazônia - IMAZON, p. 23.

BARLOW, J., GARDNER, T.A., FERREIRA, L.V. \& PERES, C.A. 2007. Litter fall and decomposition in primary, secondary and plantation forests in the Brazilian Amazon. Forest Ecol. Manag. 247(1-3):91-97.

BARLOW, J. \& PERES, C.A. 2008. Fire-mediated dieback and compositional cascade in an Amazonian forest. Philos. Trans. R. Soc. Lond. Ser. B-Biol. 363(1498):1787-1794.

BARLOW, J., LOUZADA, J., PARRY, L., HERNANDEZ, M.I.M., HAWES, J., PERES, C.A., VAZ-DE-MELLO, F.Z. \& GARDNER, T.A. 2010. Improving the design and management of forest strips in human-dominated tropical landscapes: a field test on Amazonian dung beetles. J. Appl. Ecol. 47(5):1158-1158.

BARRETO, P., AMARAL, P., VIDAL, E. \& UHL, C. 1998. Costs and benefits of forest management for timber production in eastern Amazonia. Forest Ecol. Manag. 108(1-2):9-26.

BECK, H., SNODGRASS, J.W. \& THEBPANYA, P. 2013. Long-term exclosure of large terrestrial vertebrates: Implications of defaunation for seedling demographics in the Amazon rainforest. Biol. Conserv. 163:115-121.

BICKNELL, J. \& PERES, C.A. 2010. Vertebrate population responses to reduced-impact logging in a neotropical forest. Forest Ecol. Manag. 259(12):2267-2275.

BICKNELL, J., STRUEBIG, M.J., EDWARDS, D.P. \& DAVIES, Z.G. 2014. Improved timber harvest techniques maintain biodiversity in tropical forests. Curr. Biol. 24(23):R1119-R1120.
BRAZIL. Lei n. 9.985, de 18 de julho de 2000. Regulamenta o art. 225, $\S 1^{\circ}$, incisos I, II, III e VII da Constituição Federal, institui o Sistema Nacional de Unidades de Conservação da Natureza e dá outras providências. Brasília: Congresso Nacional, 2000. p.23.

BUCKLAND, S.T., PLUMPTRE, A.J., THOMAS, L. \& REXSTAD, E.A. 2010a. Line transect sampling of primates: can animal-toobserver distance methods work? Int. J. Primatol. 31(5):485-499.

BUCKLAND, S.T., PLUMPTRE, A.J., THOMAS, L. \& REXSTAD, E.A. 2010b. Design and analysis of line transect surveys for primates. Int. J. Primatol. 31(5):833-847.

CHAPMAN, C.A., BALCOMB, S.R., GILLESPIE, T.R., SKORUPA, J.P. \& STRUHSAKER, T.T. 2000. Long-term effects of logging on african primate communities: a 28 -year comparison from Kibale National Park, Uganda. Conserv. Biol. 14(1):207-217.

CLARK, C.J., POULSEN, J.R., MALONGA, R. \& ELKAN, P.W. 2009. Logging concessions can extend the conservation estate for central african tropical forests. Conserv. Biol. 23(5):1281-1293.

COCHRANE, M.A. \& LAURANCE, W.F. 2002. Fire as a large-scale edge effect in Amazonian forests. J. Trop. Ecol. 18(3):311-325.

DE CÁCERES, M. \& LEGENDRE, P. 2009. Associations between species and groups of sites: indices and statistical inference. Ecology 90(12):3566-3574.

DE CÁCERES, M. \& JANSEN, F. 2014. Package 'indicspecies' version 1.7.4. http://cran.r-project.org/web/packages/indicspecies/indicspecies. html (last access: 09/12/2014).

DE THOISY, B., RENOUX, F. \& JULLIOT, C. 2005. Hunting in northern French Guiana and its impact on primate communities. Oryx 39(2):149-157.

EISENBERG, J.F. 1989. Mammals of the Neotropics: the northern Neotropics. The University of Chicago Press, Chicago, Illinois.

ENDO, W., PERES, C.A., SALAS, E., MORI, S., SANCHEZ-VEGA, J.L., SHEPARD, G.H., PACHECO, V. \& YU, D.W. 2010. Game vertebrate densities in hunted and nonhunted forest sites in Manu National Park, Peru. Biotropica 42(2):251-261.

FAO. 2010. Global forest resources assessment 2010. Main report. Food and Agriculture Organization, Roma, Italy, p. 378.

FEARNSIDE, P.M. 2005. Deforestation in Brazilian Amazonia: History, rates and consequences. Conserv. Biol. 19(3):680-688.

GARDNER, T.A., RIBEIRO-JUNIOR, M.A., BARLOW, J., CRISTINA, T., AVILA-PIRES, S., HOOGMOED, M.S. \& PERES, C.A. 2007. The value of primary, secondary, and plantation forests for a neotropical herpetofauna. Conserv. Biol. 21(3):775-787.

GIBSON, L., LEE, T.M., KOH, L.P., BROOK, B.W., GARDNER, T.A., BARLOW, J., PERES, C.A., BRADSHAW, C.J.A., LAURANCE, W.F., LOVEJOY, T.E. \& SODHI, N.S. 2011. Primary forests are irreplaceable for sustaining tropical biodiversity. Nature 478:378-381.

GROVE, S.J. 2002. The influence of forest management history on the integrity of the saproxylic beetle fauna in an Australian lowland tropical rainforest. Biol. Conserv. 104(2):149-171.

GUTIERREZ-GRANADOS, G. \& DIRZO, R. 2010. Indirect effects of timber extraction on plant recruitment and diversity via reductions in abundance of frugivorous spider monkeys. J. Trop. Ecol. 26(1):45-52.

INPE. 2014. Levantamento das áreas deflorestadas da Amazônia Legal no período 1988-2013: resultados Ministério da Ciência e Tecnologia. São José dos Campos, SP, Brazil. http://www.obt.inpe.br/prodes/ (last access: $14 / 06 / 13)$.

JOHNS, A.D. 1986. Effects of selective logging on the behavioral ecology of west malaysian primates. Ecology 67(3):684-694.

JOHNS, A.D. 1988. Effects of "selective" timber extraction on rain forest structure and composition and some consequences for frugivores and folivores. Biotropica 20(1):31-37.

JOHNS, A.D. 1991. Responses of Amazonian rain forest birds to habitat modification. J. Trop. Ecol. 7(4):417-437.

JOHNS, A.D. 1992. Vertebrate response to selective logging: implications for design of logging systems. Philos. Trans. R. Soc. Lond. Ser. B-Biol. Sci. 335(1275):437-442. 
JOHNS, A.G. 1996. Bird population persistence in Sabahan logging concessions. Biol. Conserv. 75(1):3-10.

JONES, M.J., MARSDEN, S.J. \& LINSLEY, M.D. 2003. Effects of habitat change and geographical variation on the bird communities of two Indonesian islands. Biodivers. Conserv. 12(5):1013-1032.

JORGE, M. 2008. Effects of forest fragmentation on two sister genera of Amazonian rodents (Myoprocta acouchy and Dasyprocta leporina). Biol. Conserv. 141(3):617-623.

KITCHING, R.L., ASHTON, L.A., NAKAMURA, A., WHITAKER, T. \& KHEN, C.V. 2013. Distance-driven species turnover in Bornean rainforests: homogeneity and heterogeneity in primary and post-logging forests. Ecography 36(6):675-682.

KOHLER, P., REINHARD, K. \& HUTH, A. 2002. Simulating anthropogenic impacts to bird communities in tropical rain forests. Biol. Conserv. 108(1):35-47.

KUDAVIDANAGE, E.P., WANGER, T.C., DE ALWIS, C., SANJEEWA, S. \& KOTAGAMA, S.W. 2012. Amphibian and butterfly diversity across a tropical land-use gradient in Sri Lanka; implications for conservation decision making. Anim. Conserv. 15(3):253-265.

LAUFER, J., MICHALSKI, F. \& PERES, C.A. 2013. Assessing sampling biases in logging impact studies in tropical forests. Trop. Conserv. Sci. 6(1):16-34.

MACPHERSON, A.J., CARTER, D.R., SCHULZE, M.D., VIDAL, E. \& LENTINI, M.W. 2012. The sustainability of timber production from Eastern Amazonian forests. Land Use Pol. 29(2):339-350.

MASON, D. 1996. Responses of venezuelan understory birds to selective logging, enrichment strips, and vine cutting. Biotropica 28(3):296-309.

MEIJAARD, E. \& SHEIL, D. 2008. The persistence and conservation of Borneo's mammals in lowland rain forests managed for timber: observations, overviews and opportunities. Ecol. Res. 23(1):21-34.

MICHALSKI, F., CRAWSHAW JR., P.G., OLIVEIRA, T.G. \& FABIÁN, M.E. 2006. Notes on home range and habitat use of three small carnivore species in a disturbed vegetation mosaic of southeastern Brazil. Mammalia 70:52-57.

MICHALSKI, F. \& PERES, C.A. 2007. Disturbance-mediated mammal persistence and abundance-area relationships in Amazonian forest fragments. Conserv. Biol. 21(6):1626-1640.

MICHALSKI, F., PERES, C.A. \& LAKE, I.R. 2008. Deforestation dynamics in a fragmented region of southern Amazonia: evaluation and future scenarios. Environ. Conserv. 35(2):93-103.

MICHALSKI, F. \& PERES, C.A. 2013. Biodiversity depends on logging recovery time. Science 339(6127):1521-1522.

NEPSTAD, D.C., VERISSIMO, A., ALENCAR, A., NOBRE, C., LIMA, E., LEFEBVRE, P., SCHLESINGER, P., POTTER, C., MOUTINHO, P., MENDOZA, E., COCHRANE, M. \& BROOKS, V. 1999. Large-scale impoverishment of Amazonian forests by logging and fire. Nature 398(6727):505-508.

NORRIS, D., MICHALSKI, F. \& PERES, C.A. 2010. Habitat patch size modulates terrestrial mammal activity patterns in Amazonian forest fragments. J. Mammal. 91(3):551-560.

OKSANEN, J., BLANCHET, F.G., KINDT, R., LEGENDRE, P., MINCHIN, P.R., O'HARA, R.B., SIMPSON, G.L., SOLYMOS, P., STEVENS, M.H.H. \& WAGNER, H. 2013. Package 'vegan' version 2.0-10. http://cran.r-project.org/web/packages/vegan/index.html (last access: 18/05/2014).

OLIVEIRA, A.C.M. \& FERRARI, S.F. 2000. Seed dispersal by blackhanded tamarins, Saguinus midas niger (Callitrichinae, Primates): implications for the regeneration of degraded forest habitats in eastern Amazonia. J. Trop. Ecol. 16(5):709-716.

OWIUNJI, I. 2000. Changes in avian communities of Budongo Forest Reserve after 70 years of selective logging. Ostrich. 71(1-2):216-219.

PACK, K.S., HENRY, O. \& SABATIER, D. 1999. The insectivorousfrugivorous diet of the golden-handed tamarin (Saguinus midas midas) in French Guiana. Folia Primatol. 70(1):1-7.
PAGLIA, A.P. \& FONSECA, G.A.B. 2009. Assessing changes in the conservation status of threatened Brazilian vertebrates. Biodivers. Conserv. 18(3):3563-3577.

PARRY, L., BARLOW, J. \& PERES, C.A. 2007. Large-vertebrate assemblages of primary and secondary forests in the Brazilian Amazon. J. Trop. Ecol. 23(6):653-662.

PARRY, L., BARLOW, J. \& PERES, C.A. 2009. Hunting for sustainability in tropical secondary forests. Conserv. Biol. 23(5):1270-1280.

PERES, C.A. 1999. General guidelines for standardizing line-transect surveys of tropical forest primates. Neotrop. Primates 7(1):11-16.

PERES, C.A. \& VAN ROOSMALEN, M. 2002. Patterns of primate frugivory in Amazonia and the Guianan shield: Implications to the demography of large-seeded plants in overhunted tropical forests. In Seed dispersal and frugivory: Ecology, evolution and conservation (Levey, D., Silva, W. \& Galetti, M., eds.). CAB International, Wallingford, UK, p. 407-423.

PERES, C.A., GARDNER, T.A., BARLOW, J., ZUANON, J., MICHALSKI, F., LEES, A.C., VIEIRA, I.C.G., MOREIRA, F.M.S. \& FEELEY, K.J. 2010. Biodiversity conservation in human-modified Amazonian forest landscapes. Biol. Conserv. 143(10):2314-2327.

PERES, C.A. 2011. Conservation in sustainable-use tropical forest reserves. Conserv. Biol. 25(6):1124-1129.

PERES, C.A. \& CUNHA, A.A. 2011. Manual para censo e monitoramento de vertebrados de médio e grande porte por transecção linear em florestas tropicais. Wildlife Conservation Society, Brasília, Brasil.

POTTS, K.B. 2011. The long-term impact of timber harvesting on the resource base of chimpanzees in Kibale National Park, Uganda. Biotropica 43(2):256-264.

POULSEN, J.R., CLARK, C.J., MAVAH, G. \& ELKAN, P.W. 2009. Bushmeat supply and consumption in a tropical logging concession in Northern Congo. Conserv. Biol. 23(6):1597-1608.

PRESLEY, S.J. 2000. Eira barbara. Mamm. Species. 636:1-6.

PUTZ, F.E., BLATE, G.M., REDFORD, K.H., FIMBEL, R. \& ROBINSON, J. 2001. Tropical forest management and conservation of biodiversity: an overview. Conserv. Biol. 15(1):7-20.

PUTZ, F.E., SIST, P., FREDERICKSEN, T. \& DYKSTRA, D. 2008. Reduced-impact logging: Challenges and opportunities. Forest Ecol. Manag. 256(7):1427-1433.

R DEVELOPMENT CORE TEAM, R.C. 2013. R: A language and environment for statistical computing Foundation for Statistical Computing. Vienna, Austria. http://cran.r-project.org/ (last access: 18/ 05/2014).

RADAM. 1974. Belém; geologia, geomorfologia, solos, vegetação e uso potencial da terra. RADAM \& BRASIL DNP/MME. Rio de Janeiro, p.478.

RAMDARSHAN, A., ALLOING-SEGUIER, T., MERCERON, G. \& MARIVAUX, L. 2011. The primate community of Cachoeira (Brazilian Amazonia): a model to decipher ecological partitioning among extinct species. PLoS One. 6(11):e27392.

RIBEIRO, M.A., GARDNER, T.A. \& ÁVILA-PIRES, T.C.S. 2008. Evaluating the effectiveness of herpetofaunal sampling techniques across a gradient of habitat change in a tropical forest landscape. J. Herpetol. 42(4):733-749.

RYLANDS, A.B. \& KEUROGHLIAN, A. 1988. Primates populations in continuous forest and fragments in central Amazonia. Acta Amaz. 18(3-4):291-307.

SAMEJIMA, H., ONG, R., LAGAN, P. \& KITAYAMA, K. 2012. Camera-trapping rates of mammals and birds in a Bornean tropical rainforest under sustainable forest management. Forest Ecol. Manag. 270:248-256.

SAMPAIO, R., LIMA, A.P., MAGNUSSON, W.E. \& PERES, C.A. 2010. Long-term persistence of midsized to large-bodied mammals in Amazonian landscapes under varying contexts of forest cover. Biodivers. Conserv. 19:2421-2439. 
SCHLEUNING, M., FARWIG, N., PETERS, M.K., BERGSDORF, T., BLEHER, B., BRANDL, R., DALITZ, H., FISCHER, G., FREUND, W., GIKUNGU, M.W., HAGEN, M., GARCIA, F.H., KAGEZI, G.H., KAIB, M., KRAEMER, M., LUNG, T., NAUMANN, C.M., SCHAAB, G., TEMPLIN, M., USTER, D., WAGELE, J.W. \& BOHNING-GAESE, K. 2011. Forest fragmentation and selective logging have inconsistent effects on multiple animalmediated ecosystem processes in a tropical forest. PLoS One. 6(11):e27785.

SHEARMAN, P., BRYAN, J. \& LAURANCE, W.F. 2012. Are we approaching 'peak timber' in the tropics? Biol. Conserv. 151(1): $17-21$.

SILVA, JR., J.S. \& NUNES, A.P. 2001. The disjunct geographical distribution of the yellow armadillo Euphractus sexcinctus (Xenarthra, Dasypodidae). Edentata 4:16-18.

SOUZA, V.R.D. (2009) Avaliação do manejo florestal das Plantações da Jari Celulose S. A. na região de Almerim, Estado do Pará Brasil. Scientific Certification System, p.53.

STONE, A.I., LIMA, E.M., AGUIAR, G.F.S., CAMARGO, C.C., FLORES, T.A., KELT, D.A., MARQUES-AGUIAR, S.A., QUEIROZ, J.A.L., RAMOS, R.M. \& SILVA JÚNIOR, J.S. 2009. Non-volant mammalian diversity in fragments in extreme eastern Amazonia. Biodivers. Conserv. 18(6):1685-1694.

TERBORGH, J., NUNEZ-ITURRI, G., PITMAN, N.C.A., VALVERDE, F.H.C., ALVAREZ, P., SWAMY, V., PRINGLE,
E.G. \& PAINE, C.E.T. 2008. Tree recruitment in an empty forest. Ecology 89(6):1757-1768.

THIOLLAY, J.M. 1992. Infuence of selective logging on bird species diversity in a Guianan rain forest. Conserv. Biol. 6(1):47-63.

THIOLLAY, J.M. 1997. Disturbance, selective logging and bird diversity: a Neotropical forest study. Biodivers. Conserv. 6:1155-1173.

UHL, C. \& VIEIRA, I.C.G. 1989. Ecological impacts of selective logging in the Brazilian Amazon: a case study from the Paragominas region of the State of Pará. Biotropica 21(2):98-106.

WHITMAN, A.A., HAGAN, J.M. \& BROKAW, N.V.L. 1998. Effects of selection logging on birds in northern belize. Biotropica 30(3):449-457.

WILliS, K.J., ARAÚJO, M.B., BENNETT, K.D., FIGUEROARANGEL, B., FROYD, C.A. \& MYERS, N. 2007. How can a knowledge of the past help to conserve the future? Biodiversity conservation and the relevance of long-term ecological studies. Philos. Trans. R. Soc. Lond. Ser. B-Biol 362(1478):175-186.

WILlOTT, S.J., LIM, D.C., COMPTON, S.G. \& SUTTON, S.L. 2000. Effects of selective logging on the butterflies of a Bornean rainforest. Conserv. Biol. 14(4):1055-1065.

WRIGHT, S.J., STONER, K.E., BECKMAN, N., CORLETT, R.T., DIRZO, R., MULLER-LANDAU, H.C., NUNEZ-ITURRI, G., PERES, C.A. \& WANG, B.C. 2007. The plight of large animals in tropical forests and the consequences for plant regeneration. Biotropica 39(3):289-291. 